\title{
Jakość życia osób w środowisku wiejskim po zawale mięśnia sercowego
}

\author{
Resident's quality of life in a rural area after myocardial \\ infarction
}

AGNIESZKA SZYMAŃSKA ${ }^{1}$ GRAŻYNA CHOJNACKA - KOWALEWSKA 2 JOANNA PRZYBYLSKA ${ }^{3}$

\footnotetext{
1 Przychodnia Lekarska Eskulap s.c. Chełmno 21, 62-660 Dąbie

2 Instytut Nauk o Zdrowiu Państwowej Uczelni Zawodowej we Włocławku, Odział Medycyny Paliatywnej, Wojewódzki Szpital Specjalistyczny im. Bł. ks. J. Popiełuszki we Włocławku

${ }^{3}$ Instytut Nauk o Zdrowiu Państwowej Uczelni Zawodowej we Włocławku
}

DOI: https://dx.doi.org/10.21784/lwP.2019.021

ISSN: 2451-1846

\section{Streszczenie:}

Wstęp. W obecnych czasach choroby układu sercowo - naczyniowego, w tym zawał mięśnia sercowego, są najczęściej występującym schorzeniem zarówno w Polsce, jak i innych krajach wysokorozwiniętych. Może to prowadzić do spadku jakości życia takich chorych.

Cel. Celem pracy jest uzyskanie informacji na temat oceny jakości życia osób w środowisku wiejskim po zawale mięśnia sercowego.

Materiał i metody. W badaniach zastosowano metodę sondażu diagnostycznego. Jako technikę dla uzyskania zamiarów badawczych wybrano ankietę. Za narzędzie badawcze posłużył dla oceny jakości życia sondaż diagnostyczny.

Do głównych technik badawczych stosowanych $\mathrm{w}$ metodzie sondażu diagnostycznego należą: technika ankiety i wywiad kwestionariuszowy.

Do analizy statystycznej wykorzystano test niezależności chi - kwadrat (zwany inaczej testem Pearsona) służący sprawdzaniu hipotez. 
Wyniki. Na podstawie otrzymanych wyników i ich analizy stwierdzono, że jakość życia wśród respondentów jest oceniana pozytywnie. Czynniki socjodemograficzne takie jak: stan cywilny, wsparcie od najbliższych, sytuacja materialna, miejsce zamieszkania są wprost proporcjonalne i wywierają na tę ocenę istotny wpływ.

Wnioski. Badani pacjenci ocenili pozytywnie jakość życia po zawale mięśnia sercowego. Pacjenci funkcjonujący w związkach, wspierani przez rodzinę i przyjaciół cechowali się lepszą jakością życia. Analizy wykazały, że czynnikami wpływającymi na jakość życia było również współwystępowanie cukrzycy i miażdżycy u chorych. Natomiast współwystępowanie nadciśnienia tętniczego i otyłości nie wykazały wpływu na jakość życia badanych.

Słowa kluczowe: jakość życia, zawał mięśnia sercowego, środowisko wiejskie

\begin{abstract}
:
Introduction. Nowadays cardiovascular diseases, including myocardial infarction, are one of the most common disorders not only in Poland but also in highly developed countries. Cardiovascular diseases my lead to decline in quality of life.

Aim. The aim of this study is to gain information on the assesment of quality of life in a rural area in people after myocardial infarction.

Material and methods. A diagnostic survey and a questionnaire were used . A diagnostic survey on the assesment of the quality of life was used as a tool. The main research techniques in the diagnostic survey were: questionnaire and questionnaire-based interviews. Chi square test (Pearson's correlation test) was used in statistical analisys.

Results. Based on the results obtained, it was concluded that the respondents' quality of life was assesed positively. Socio-demographic features such as: marital status, families' support, financial situation, place of residence are directly proportional and have significant impact on the assesment.
\end{abstract}


Conclusions. In this study, patients assessed the quality of life after myocardial infarction positively. Patients who are married, supported by their families and friends presented a better quality of life. Analyses showed that coexistence of diabetes and atherosclerosis have also a great influence on patients' quality of life. However, arterial hypertension and obesity have no impact on the quality of life.

Keywords: quality of life, myocardial infarction, a rural area

\section{Wstęp}

Najnowsze badania wykazują, że rocznie notowanych jest w Polsce ok. 90 tys. zawałów serca. Częstość zawałów występujących przed 45. r.ż. szacuje się na 10 proc. wszystkich przypadków zawałów. Zdecydowaną większość stanowią mężczyźni, jednak obserwuje się tendencję do wzrostu liczby zawałów również u młodych kobiet, które stanowią ok. 20 proc. pacjentów z zawałem serca przed 55. rokiem życia [1].

Mamcarz, twierdzi, że choroby układu krążenia są nadal główną przyczyną zgonów w Polsce. Rocznie z ich powodu umiera 177 tys. osób. Każdego roku 80-100 tys. osób przechodzi zawał mięśnia sercowego [2].

Obecnie widzimy, że nasz tryb życia nie sprzyja polepszeniu kondycji układu krążenia. W dzisiejszych czasach możemy zaobserwować u ludzi szybki tryb życia, brak odpowiedniej ilości snu i odpoczynku, nieprzestrzeganie zasad zdrowego żywienia, a także niski poziom aktywności fizycznej. Te wszystkie czynniki sprzyjają rozwojowi chorób sercowo - naczyniowych.

Najczęstszą przyczyną zawału mięśnia sercowego jest miażdżyca naczyń wieńcowych - występuje w ok. 98\% przypadków. Przyczyną ostrego zespołu wieńcowego jest zaburzenie równowagi między zapotrzebowaniem mięśnia sercowego na tlen a podażą tlenu, najczęściej wskutek nagłego ograniczenia drożności tętnicy 
wieńcowej przez zakrzep powstający na uszkodzonej blaszce miażdżycowej. Zakrzep może ograniczać lub zamknąć przepływ wieńcowy [3].

Zawał mięśnia sercowego to śmierć jego komórek z powodu braku ich prawidłowego zaopatrzenia w krew, która dostarcza do nich tlen i substancje odżywcze. Jest nagłym, ostrym stanem kardiologicznym, który wymaga szybkiej pomocy medycznej. Brak prawidłowego zaopatrzenia mięśnia sercowego w krew wynika ze zwężenia lub zamknięcia naczynia wieńcowego. Doprowadza to do ograniczenia lub braku przepływu krwi, powodując niedokrwienie z następczą martwicą [4].

Celem leczenia zawału serca w ostrym okresie jest jak najszybsze przywrócenie drożności tętnic wieńcowych. Po leczeniu inwazyjnym należy dążyć do zmniejszenia prawdopodobieństwa wystąpienia kolejnego incydentu wieńcowego oraz do redukcji ryzyka rozwoju niewydolności serca [5].

Prawidłowa ocena ryzyka, a potem profilaktyka wtórna po zawale serca, stanowi podstawę opieki nad pacjentami po przebytym zawale serca [6].

W medycynie problemami jakości życia zajmują się: psycholodzy kliniczni, lekarze, socjolodzy, pielęgniarki i specjaliści zdrowia publicznego. Terminem tym określa się całościowe spojrzenie na problemy pacjenta $w$ zakresie zdrowia fizycznego, psychicznego, a także środowiska. Wiedza ta dostarcza nam informacji na temat funkcjonowania pacjenta w ważnych dziedzinach życia, a także ocena efektywności leczenia, monitorowania wpływu leków. Pomaga w zorganizowaniu doraźnej i długotrwałej opieki [7].

Przewlekłe schorzenia znacznie obniżają jakość życia, dlatego współczesna medycyna dąży do przywrócenia zaburzonych funkcji organizmu obejmując chorego kompleksową, holistyczną opieką. 
Pacjent jest partnerem w procesie leczenia, dlatego też ocena sytuacji, w której się znalazł jest zasadnicza dla procesu leczenia [8].

\section{Cel}

Celem niniejszej pracy jest analiza wybranych obiektywnych oraz subiektywnych czynników wpływających na ocenę jakości życia osób w środowisku wiejskim po zawale mięśnia sercowego.

\section{Materiał i metody}

W pracy zastosowano metodę sondażu diagnostycznego. Jako technikę dla uzyskania zamiarów badawczych wybrano ankietę. Za narzędzie badawcze posłużył niezbędny dla oceny jakości życia, opracowany samodzielnie - kwestionariusz ankiety, który zawiera 24 pytania. Kwestionariusz przeznaczony jest dla osób w środowisku wiejskim po przebytym zawale mięśnia sercowego. Pytania w kwestionariuszu dotyczą między innymi: stanu cywilnego, wykształcenia, aktywności zawodowej, ilości przebytych zawałów serca, obecnej jakości życia, sytuacji materialnej, wizyt kontrolnych u lekarzy specjalistów, współistniejących chorób, trybu życia, aktywności fizycznej, wsparcia najbliższych.

Badania miały charakter anonimowy. Warunkiem ich przeprowadzenia była dobrowolna zgoda pacjenta na udział w procedurze badawczej. Analizę statystyczną przeprowadzono przy użyciu programu Statistica wersja 10.0 firmy Statsoft Polska. Wyniki badań poddane zostały szczegółowej analizie statystycznej za pomocą testu niezależności chi - kwadrat (zwany inaczej testem Pearsona).

W przeprowadzonych badaniach wzięło udział 70 osób. Wśród nich znajdowali się przedstawiciele obu płci. Większą grupę ankietowanych stanowili mężczyźni - 36 osób, tj. 51,4\%, mniejszą zaś kobiety, bo 34 osoby, co daje $48,6 \%$. 
Kolejnym elementem różnicującym ankietowane osoby, był różny przedział wiekowy. Najliczniejszą grupą respondentów stanowiły osoby w przedziale wiekowym 55 - 65 lat i stanowiło to 35 osób badanych (50\%). Mniej liczną grupę stanowiły osoby $\mathrm{w}$ przedziale wiekowym 65 - 75 lat, czyli 21 osób (30\%). I adekwatnie do wcześniejszych wyliczeń, trzecia grupa badanych, najmniejsza, mieści się w przedziale wiekowym 45 - 55 lat, co stanowi 14 osób (20\% ogółu badanych).

Najwięcej respondentów mieszkało ze współmałżonkiem, bo 64,3\% ogółu, znacznie mniejszą grupę stanowią osoby stanu wolnego, analiza ankiety wykazała, że to 35,7\% ogółu badanych.

W pytaniu dotyczącym wykształcenia ankietowanych zarówno wykształcenie zawodowe, jak i średnie zostało zaznaczone przez taką samą ilość badanych osób i stanowi to 34,3\%. Natomiast wykształcenie podstawowe wykazuje $20 \%$ ogółu badanych. Najmniejszą grupą, bo tylko 11,4\% ogółu badanych - wykazuje się wykształceniem wyższym.

Badania przeprowadzono na terenie województwa kujawskopomorskiego, wśród pacjentów lekarza rodzinnego w Przychodni Lekarskiej Eskulap w Chełmnie.

\section{Wyniki}

Zdecydowana większość osób, których „dotknęła” choroba, to ludzie, starsi, przebywający już na emeryturze ( $40 \%$ ankietowanych), pozostali to renciści $(34,3 \%)$ oraz osoby pracujące $(22 \%)$. Większość respondentów, bo aż 75,7\%, doświadczyło tylko jeden zawał mięśnia sercowego, natomiast dwa zawały mięśnia sercowego przechorowało 24,3\% ogółu badanych.

Analiza sytuacji materialnej ankietowanych wykazała zrównoważenie, ponieważ 54,3\% badanych stwierdza, iż ich sytuacja materialna pogorszyła się po zawale mięśnia sercowego, natomiast 
$40 \%$ ogółu badanych stwierdza, że sytuacja materialna nie uległa zmianie. Ankieta wykazała również takie osoby, u których sytuacja materialna wręcz polepszyła się (5,7\% badanych).

Bardzo istotnym elementem decydującym o częstości wizyt kontrolnych u lekarza specjalisty kardiologa jest odległość, jaką muszą respondenci pokonać, od swojego miejsca zamieszkania do poradni kardiologicznej. Większość osób $(81,4 \%)$, deklaruje, że poradnia kardiologiczna znajduje się powyżej $30 \mathrm{~km}$ od jej miejsca zamieszkania, co stanowi problem z samodzielnym dotarciem do lekarza prowadzącego. 65,7\% ogółu ankietowanych nie może samodzielnie dojechać i musi korzystać z pomocy innych.

Wśród 70 osób po przebytym zawale mięśnia sercowego, aż $81,4 \%$ badanych, choruje również na nadciśnienie tętnicze. Co wskazuje na występowanie wzajemnych zależności między nadciśnieniem tętniczym a występowaniem zawału mięśnia sercowego. Niewiele mniej, bo aż $67,1 \%$ badanych choruje również na miażdżycę. Uwidacznia się również zależność pomiędzy osobami po przebytym zawale mięśnia sercowego a występowaniem rozpoznanych chorób serca w rodzinach. U większości badanych, czyli u 78,6\%, ktoś inny z rodziny miał już rozpoznaną chorobę układu krążenia. Tylko u $21,4 \%$ badanych nikt inny w rodzinie nie miał rozpoznanej choroby układu krążenia.

Wiodącą tendencją wśród ankietowanych jest zmniejszona aktywność fizyczna, 75,7\% ogółu badanych prowadzi mniej aktywny tryb życia po zawale serca, z czego $70 \%$ badanych obawia się utraty życia po wysiłku fizycznym. Tylko pojedynczy pacjenci $(8,6 \%$ ogółu) potwierdzili, że prowadzą bardziej aktywny tryb życia niż przed zawałem. Dlatego nie dziwi, brak korzystania $\mathrm{z}$ rehabilitacji kardiologicznej. Niestety aż $78,6 \%$ badanych nie korzystało z rehabilitacji kardiologicznej, a zaledwie $21,4 \%$ badanych skorzystało z przysługującej im procedury. To może odzwierciedlać niską wiedzą 
na temat czynników ryzyka zawału mięśnia sercowego. Tylko 25,7\% badanych zna czynniki, które mogą wywołać zawał mięśnia sercowego. Pozostała część osób - 64,3\% badanych nie zna wszystkich czynników ryzyka zawału mięśnia sercowego i aż $10 \%$ badanych nie zna wcale czynników ryzyka zawału mięśnia sercowego. Na zadane pytanie, które dotyczyło palenia papierosów, największa grupa badanych (44,3\%), rzuciła palenie papierosów dopiero po wystąpieniu zawału. Niestety mimo przechorowania zawału, 5,7\% nada pali papierosy. Cieszy jedynie, iż 35,7\% nie pali papierosów wcale. Podobnie wygląda sprawa spożywania alkoholu. Największa grupa badanych, bo aż $55,7 \%$ nie pije alkoholu, $40 \%$ badanych pije alkohol okazjonalnie i mimo przechorowania zawału $4,3 \%$ badanych często pije alkohol.

Dokonano także analizy wsparcia najbliższych. Poczucie wsparcia daje wrażenie stabilności emocjonalnej, przezwyciężenia trudności i problemów występujących u osoby po przejściach zdrowotnych. Umożliwia ono zwiększenie poczucia własnej wartości, stanowi ważny czynnik motywujący do „walki” o własne zdrowie. Wskazując źródła wsparcia respondenci podkreślali tutaj szczególnie udział rodziny, większość badanych - 61,4\%, miało wsparcie najbliższych w czasie choroby.

Analiza zebranych ankiet pozwoliła ocenić zadowolenie z jakości życia pacjentów po przebytym zawale mięśnia sercowego zamieszkujących wieś. Jakość życia osób po zawale jest oceniana dobrze przez $37,1 \%$ ogółu badanych, bardzo dobrze przez $24,3 \%$, zadowalająco przez 21, 5\%. Znaczna mniejszość badanych - 17,1\% określa źle swoją jakość życia. Możemy zatem przyjąć, że jakość życia osób po zawale mięśnia sercowego w środowisku wiejskim oceniana jest pozytywnie. 


\section{Dyskusja}

Choroby układu krążenia, a zwłaszcza zawał mięśnia sercowego, stanowią poważny problem zdrowotny obecnych czasów. Rozwój medycyny sprawił, że zdecydowana większość chorych przeżywa zawał mięśnia sercowego. Niestety nie zawsze mogą powrócić do swojej pracy zawodowej, czy kontynuować życie w podobnej formie. Ma to wpływ na jakość ich życia [9]. W badaniach przeprowadzonych w 2011 roku w Klinice Kardiologii 10-go Wojskowego Szpitala Wojskowego z Politechniką w Bydgoszczy wykazano, że 73,3\% badanych była zadowolonych ze swojej jakości życia. Wyniki badań własnych wykazują, że jakość życia osób po zawale w środowisku wiejskim oceniana jest pozytywnie - dobrze przez $37,1 \%$ ogółu badanych, bardzo dobrze przez 24,3\%, zadowalająco przez 21, 5\%. Można zatem przyjąć, że łącznie 82,9\% badanych w środowisku wiejskim jest zadowolona z jakości życia po zawale mięśnia sercowego [9].

Zawał mięśnia sercowego w większości przypadków jest sytuacją zaskakującą zarówno pacjenta, jak i jego rodzinę. Bezpośrednie zagrożenie życia pojawia się nagle, powoduje szereg negatywnych reakcji w psychice. Jest silnym stresem, sytuacją kryzysową, dotyka podstaw dotychczasowego życia pacjenta, jego relacji z otoczeniem. Zagraża wartościom, ingeruje w życie jednostki, zmusza do przystosowania się do zmienionej sytuacji [10]. Wyniki badań własnych wykazują, że otrzymywanie wsparcia od najbliższych w czasie choroby jest czynnikiem, który w istotny statystycznie sposób wpływa na ocenę jakości życia wyrażaną przez pacjentów po zawale. Wśród osób wspieranych przez rodzinę i przyjaciół udział ocen bardzo dobrych lub dobrych wyniósł 76,7\%, natomiast w gronie nieposiadających wsparcia wskaźnik ten wynosi jedynie $37 \%$. Przeprowadzona analiza badań wykazała także istnienie istotnego statystycznie związku pomiędzy stanem cywilnym osób po zawale, 
a wyrażanymi przez nich ocenami jakości życia. Pacjenci funkcjonujący $\mathrm{w}$ związkach cechują się lepszą jakością życia od pacjentów stanu wolnego. W grupie osób żyjących samotnie odsetek ocen bardzo dobrych lub dobrych wyniósł zaledwie $20 \%$, podczas gdy w gronie osób posiadających partnera udział ten wyniósł aż $84,4 \%$. Na podstawie przeprowadzonych badań można również zauważyć, że w grupie osób, u których sytuacja materialna nie zmieniła się na gorsze, udział ocen bardzo dobrych lub dobrych wyniósł aż 96,9\%, a wśród tych, którzy doświadczyli pogorszenia się sytuacji, odsetek ten był dużo niższy bo wyniósł $31,6 \%$. W badaniach nie można stwierdzić jednoznacznie czy na jakość życia wpływa sytuacja materialna, czy też jakość życia ma wpływ na sytuację materialną badanych. Wśród grupy respondentów można zauważyć, że zawał mięśnia sercowego wymusił u większej części ogółu - tj. 48,6\%, zmianę pracy, 35,7\% ogółu badanych musiało zrezygnować z pracy i tylko $15,7 \%$ badanych osób pracuje tak jak przed chorobą.

Dużym problemem ludzi mieszkających $\mathrm{w}$ środowisku wiejskim jest brak poradni kardiologicznych blisko miejsca zamieszkania. Badania za pomocą ankiety dowiodły, że osoby mieszkające w odległości do 30 kilometrów od najbliższej poradni kardiologicznej zdecydowanie częściej wyrażają dobre lub bardzo dobre opinie o jakości swojego życia od pacjentów, którzy mają dalej do specjalisty. Wśród badanych tylko 34,3\% ogółu może samodzielnie dojechać do swojego lekarza prowadzącego, natomiast zdecydowana większość badanych, bo aż $65,7 \%$ ogółu musi korzystać z pomocy innych.

Coraz częściej źródłem pełnej informacji o pacjentach są czułe i wiarygodne testy oceniające wydolność i tolerancję wysiłku oraz subiektywną ocenę samopoczucia i funkcjonowania $\mathrm{w}$ życiu codziennym, są one dokonywane przez pacjenta [11]. W badaniach wykonanych za pomocą ankiety, wykazano, że u 24,3\% badanych 
aktywność fizyczna po zawale mięśnia sercowego nie jest mniejsza niż przed zawałem. Natomiast aż u 70\% badanych aktywność fizyczna jest mniejsza niż przed zawałem z powodu obawy utraty życia po wysiłku, u 54,3\% badanych z powodu obawy przed kolejnym zawałem, zaś u 47,1\% występuje lęk przed bólem. Bez odpowiedzi pozostaje pytanie, czy możliwy jest powrót wydolności takich chorych do poziomu osób zdrowych. Wydaje się, że dylemat ten można rozstrzygnąć w oparciu o porównanie efektów psycho - fizycznych zastosowanej rehabilitacji z wynikami osiąganymi przez osoby zdrowe.

W badaniach klinicznych dotyczących skutków chorób układu sercowo-naczyniowego zaczęto odchodzić od zasady wyłącznie biologicznej oceny zdrowia człowieka, przyjmując wieloaspektowy punkt widzenia, w którym dużą uwagę zwraca się na jakość życia zależną od stanu zdrowia pacjenta [12]. Badania własne wykazały, że wśród znacznie większej grupy osób chorujących na zawał mięśnia sercowego ktoś z rodziny miał wcześniej rozpoznaną chorobę układu krążenia i było to aż $78,6 \%$ badanych. Na jakość życia osób po zawale mięśnia sercowego mają wpływ choroby współistniejące. W badaniu własnym tylko $7,1 \%$ badanych nie choruje na inne choroby, zaś $81,4 \%$ badanych choruje na nadciśnienie tętnicze, niewiele mniej, bo $67,1 \%$ na miażdżycę, $37,1 \%$ na cukrzycę, najmniej osób badanych, bo $18,6 \%$ ma otyłość. Z badań wynika, że osoby, które chorują na cukrzycę wyrażają gorsze opinie na temat jakości swojego życia od osób, które nie mają cukrzycy. W podobny sposób chorujący na miażdżycę wyrażają gorsze opinie na temat jakości swojego życia, a odsetek ocen bardzo dobrych i dobrych jest o niemal 40 punktów procentowych wyższy wśród osób, które nie chorują na miażdżycę. Natomiast współwystępowanie nadciśnienia tętniczego nie wpływa istotnie na wyrażane oceny jakości życia ( $\mathrm{p}=0,5219)$, choć można zauważyć, że odsetek ocen bardzo dobrych lub dobrych jest niższy $w$ gronie cierpiących na nadciśnienie. Podobnie osoby dotknięte otyłością 
wyrażają nieco gorsze opinie na temat jakości swojego życia, natomiast nie jest to różnica dająca podstawy do wykazania związku, a zmienne nie są skorelowane. Być może powtórzenie badania na większej grupie osób $\mathrm{z}$ otyłością, czy nadciśnieniem tętniczym przyniosłoby odmienne rezultaty.

Zapewnienie wysokiego poziomu jakości życia ma być głównym celem wielu sektorów - rządowych i lokalnych społeczności, $\mathrm{w}$ odniesieniu do organizacji systemu opieki zdrowotnej. Wizyty pacjentów z chorobami przewlekłymi mogą sięgać 80\% wszystkich przyjęć w ramach podstawowej opieki medycznej. $\mathrm{W}$ tej grupie jest u 15\% chorych występują co najmniej trzy choroby przewlekłe, a 30\% hospitalizacji jest konsekwencją zaostrzenia stanu klinicznego chorych z tymi chorobami. Wynik oceny jakości życia może być wskaźnikiem poziomu niezaspokojonych potrzeb tych pacjentów [12].

\section{Wnioski}

Analiza materiału badawczego pozwala na sformułowanie następujących wniosków:

1. Jakość życia osób po zawale mięśnia sercowego w środowisku wiejskim oceniana jest pozytywnie.

2. Na jakość życia osób po zawale mięśnia sercowego w środowisku wiejskim wpływa stan cywilny. Pacjenci funkcjonujący w związkach cechują się lepszą jakością życia od pacjentów stanu wolnego.

3. Otrzymywanie wsparcia od najbliższych jest czynnikiem wpływającym na ocenę jakości życia osób w środowisku wiejskim po zawale mięśnia sercowego. Wśród osób wspieranych przez rodzinę i przyjaciół zdecydowana większość ocenia jakość życia bardzo dobrze i dobrze.

4. Sytuacja materialna wpływa na jakość życia pacjentów po zawale mięśnia sercowego w środowisku wiejskim. U osób, u których nie nastąpiła negatywna zmiana dochodów cechują się zdecydowanie 
lepszą jakością życia od osób, u których skutkiem zawału było zmniejszenie dochodów.

5. W środowisku wiejskim jest utrudniony dostęp do lekarzy specjalistów i wpływa to na jakość życia osób po zawale mięśnia sercowego. Problemem dla pacjentów jest duża odległość od poradni kardiologicznej i u większości konieczność korzystania z pomocy innych osób, aby tam dojechać.

6. Choroby współistniejące u chorych po zawale mięśnia sercowego mają wpływ na jakość życia na wsi. Analiza wykazała, że czynnikami wpływającymi na jakość życia jest współwystępowanie cukrzycy i miażdżycy u chorych i są to hipotezy potwierdzone. Natomiast analiza współwystępowania nadciśnienia tętniczego i otyłości nie wykazała związku pomiędzy zmiennymi i nie ma podstaw do przyjęcia tej hipotezy.

\section{Zalecenia dla praktyki pielęgniarskiej}

Pielęgniarka będąc członkiem interdyscyplinarnego zespołu terapeutycznego aktywnie uczestniczy w adaptacji pacjentów do nowej sytuacji zdrowotnej i optymalizacji jakości ich życia. Ma możliwość kształtowania i wpływ na poprawę jakości życia chorych po przebytym zawale mięśnia sercowego.

\section{Bibliografia / Bibliography:}

1. Narodowa Baza Danych Zawałów Serca. AMI-PL. 2009 - 2012.

2. Kossobudzka M. 46 proc. zgonów w Polsce następuje w wyniku chorób układu krążenia. Retrieved 16 marca, 2018, https://wyborcza.pl/Tylko Zdrowie/

3. Szczeklik A. Gajewski P. Interna Szczeklika 2017/2018. Mały Podręcznik., Wydawnictwo Medycyna Praktyczna, Kraków, 2017. 
4. Sałacki A. Zawał mięśnia sercowego. Medycyna Po Dyplomie 2017;05. https://podyplomie.pl/medycyna/26806,zawal-miesnia-sercowego

5. Kubica J., Sienkiewicz W. Chory po zawale serca. Wydawnictwo Via Medica, Gdańsk, 2008.

6. Opolski G., Filipiak K., Grabowski M. Ocena ryzyka i leczenie po zawale serca. Przew. Lek. 2003;6,7/8:44-55.

7. Trzebiatowski J. Jakość życia $\mathrm{w}$ perspektywie nauk społecznych i medycznych - systematyzacja ujęć definicyjnych. Hygeia Public Health. 2011;46,(1):25-31.

8. Muszalik M., Kędziora-Kornatowska K. Jakość życia a stan zdrowia. Magazyn Pielęgniarki i Położnej 2007; 5,24-25.

9. Orłowski P., Humańska M. Jakość życia pacjentów po zawale mięśnia sercowego. Pielęgniarstwo w Opiece Długoterminowej, Wydawnictwo PWSZ w Płocku, 2017;2(3):29-44.

10. Szczygielska-Majewska M., Majcher P., Bulikowski W., Stawińska T., Jaracz E., Problemy osób po zawale mięśnia sercowego na etapie rehabilitacji uzdrowiskowej. Balneologia Polska. 2008;1:24-28.

11. Smolis - Bąk E. i wsp. Ocena porównawcza wydolności fizycznej i wybranych aspektów psychologicznych pacjentów rehabilitowanych w szpitalu po zawale mięśnia sercowego jednej tętnicy leczonych bezpośrednią angioplastyką wieńcowa(PTCA). Postępy rehabilitacji 2010;(1):37-42.

12. Pałczak E., Uchmanowicz I. Analiza czynników wpływających na jakość życia po zawale mięśnia sercowego. Piel. Zdr. Publ. 2012;2,1:29-37.

13. Kurpas J. Domena środowiskowa jakości życia osób przewlekle chorych, Lek. Wojsk. 2016;94(1):23-27. 
Innowacje w Pielęgniarstwie i Naukach o Zdrowiu

$4(4) / 2019$

Otrzymano: 12.05.2019r.

Zaakceptowano: $01.06 .2019 \mathrm{r}$.

23700 znaków 